\title{
石炭灰と頁岩微粉末を原料とした高強度人工軽量骨材の開発に関する研究 DEVELOPMENT OF ARTIFICIAL HIGH STRENGTH LIGHT WEIGHT AGGREGATE MADE FROM COAL ASH AND EXPANDING SHALE POWDER
}

\author{
笠井 浩*1, 全 振 煥*2, 和美廣喜*3 \\ 藤木英一 ${ }^{* 4}$, 田中公徳 ${ }^{*}$, 齋藤昭雄*6 \\ Hiroshi KASAI, Jinhwan JEON, Hiroki WAMI, \\ Eiichi FUJIKI, Kiminori TANAKA and Akio SAITO
}

\begin{abstract}
This research is able to develop the artificial light-weight aggregate made from a coal ash and a shale fine powder as main raw materials, and use a large amount of coal ash effectively as an aggregate for concrete. As a result, this newly developed aggregate can be manufactured by using existing facility for a sintered shale light-weight aggregate, and it can be confirmed that it was an high-performance aggregate which maintained lightness, high strength, and high water retentivity and harder composition compared with several existing and marketing light-weight aggregates. Moreover, this aggregate obtained the various physical properties by changing the compounding ratio of the raw material of two elements.
\end{abstract}

Keywords : Coal ash, Expanding Shale Powder, Artificial light-weight aggregate, High strength, Quality of aggregate 石炭灰, 頁岩微粉末, 人工軽量骨材, 高強度, 骨材品質

\section{1.はじめに}

わが国の石炭火力発電所等から排出される石炭灰の発生量は2005年 度において, 約834万トンにも達し, 2010年には1000万トンに増大寸るこ とが予測されており，その有効利用が急務となっている。良質な石炭灰 は, セメントの粘土代替材やコンクリート用混和材などに利用されてい るが, 粗粉など品質の良くない石炭灰は埋め立て処分されている。

石炭灰の最終処分場の確保も困難な状況になりつつあり，未利用資 源の有効利用技術の確立が重要な課題となっている。

一方，コンクリートに使用されている天然骨材は砕石を含め, 今まで 大量に消費されてきており，良質な骨材の枯渇が危惧されている。地球 環境の保全や循環型社会形成の観点からも，天然骨材は，今後むや夕に 採掘することは好ましくない状況になってきた。

このような背景から，石炭灰を大量に有効利用できるコンクリート 用骨材を開発することは，極めて重要なことと言える。

筆者らは1999年度から石炭灰と頁岩微粉末を原料とする軽量骨材の

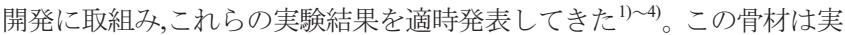
用化され，実構造物にも使用されている。本論文はこれらの結果を踏ま え,この開発研究を体系的に整理し未発表の資料を加えてまとめたもの である。

石炭灰を原料とするコンクリート用骨材としては, 旧くは昭和 40 年頃
に試作品が製造された。その後,昭和60年頃に国内産の石炭灰と少量の微 粉炭を原料とした人工軽量骨材 ${ }^{5)}$ が開発されている。この骨材は軽量か つ15\%以上の高い吸水率を有する。これを用いたコンクリートは頁岩系 軽量骨材コンクリートとほぼ同程度の強度であるが，乾燥収縮や中性化 など耐久性に係わる性質は若干劣っている。この理由として, 骨材の焼 成温度が低いことを挙げ, 骨材表面が膨張頁岩系軽量骨材よりも粗面状

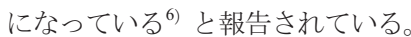

最近では，石炭灰，ベントナイト，石灰石微粉末を原料とした絶乾密 度1.8 2.1 $\mathrm{g} / \mathrm{cm}^{3}$ 程度の高強度人工骨材 ${ }^{7}$ が開発されている。この骨材 はやや密度が大きいためコンクリートとしての軽量化の効果は比較的 少ないことや焼成温度が $1300^{\circ} \mathrm{C}$ 程度と高温のため, 焼成時の熱エネルギ 一を多く必要とする。

筆者 ${ }^{1)^{2}}$ による実験の結果では,石炭灰と頁岩微粉末の混合比率を 60 : 40にすることにより，焼成した骨材の圧壊荷重は 1000 N以上を有し， 絶乾密度 $1.51 \mathrm{~g} / \mathrm{cm}^{3}$ ，吸水率 $8.2 \%$ 石炭灰人工軽量骨材が得られた。ま た，石炭灰と頁岩微粉末の混合比率を変化させることによって，焼成後 の骨材の物性をコントロールすることができる見通しが得られた。

そこでこれらの結果を踏まえて,省エネルギー化を図るために1100〜 $1200{ }^{\circ} \mathrm{C}$ で溶融する頁岩微粉末に着目し, 石炭灰と頁岩微粉末を混合・造 粒および焼成した軽量（絶乾密度 $1.55 \pm 0.15 \mathrm{~g} / \mathrm{cm}^{3}$ ），高強度（圧壊荷重
*1 鹿島建設(侏)技術研究所 上席研究員 · 工修

*2 鹿島建設株技術研究所 主任研究員・博士 (工学)

*3 島根大学総合理工学部 教授·工博

*4 人工軽量骨材協会 事務局長

*5 日本メサライト工業(株) 技術課長

*6 常磐共同火力株勿来発電所 副所長
Chief Research Engineer, Kajima Technical Research Institute, M. Eng. Senior Research Engineer, Kajima Technical Research Institute, Dr. Eng.

Prof., Interdisciplinary Faculty of Science and Engineering, Shimane Univ., Dr. Eng.

Director, Artificial Light Weight Aggregate Association

Technical Manager, Nihon Mesalite Industry Co., Ltd.

Deputy General Manager, Joban Joint Power Co., Ltd., Nakoso Power Station 
表 1 頁岩微粉末と石炭灰の組成分析結果

\begin{tabular}{c|c|c|c|c|c|c|c|c|c|c}
\hline 分析試料 & $\begin{array}{c}\mathrm{SiO}_{2} \\
(\%)\end{array}$ & $\begin{array}{c}\mathrm{Al}_{2} \mathrm{O}_{3} \\
(\%)\end{array}$ & $\begin{array}{c}\mathrm{Fe}_{2} \mathrm{O}_{3} \\
(\%)\end{array}$ & $\begin{array}{c}\mathrm{MgO} \\
(\%)\end{array}$ & $\begin{array}{c}\mathrm{CaO} \\
(\%)\end{array}$ & $\begin{array}{c}\mathrm{Na}_{2} \mathrm{O} \\
(\%)\end{array}$ & $\begin{array}{c}\mathrm{K}_{2} \mathrm{O} \\
(\%)\end{array}$ & $\begin{array}{c}\text { ig.loss } \\
(\%)\end{array}$ & $\begin{array}{c}\text { 湿分 } \\
(\%)\end{array}$ & $\begin{array}{c}\text { 計 } \\
(\%)\end{array}$ \\
\hline 頁岩微粉末 & 69.30 & 13.10 & 2.29 & 1.60 & 1.62 & 1.31 & 2.37 & 5.58 & - & 95.57 \\
\hline 石炭灰A & 42.50 & 20.80 & 6.00 & 1.95 & 18.70 & 1.38 & 1.08 & 3.39 & 0.06 & 95.86 \\
\hline 石炭灰 $\mathrm{B}$ & 42.84 & 25.72 & 8.13 & 1.26 & 12.62 & 0.92 & 1.04 & 3.00 & 0.16 & 95.69 \\
\hline 石炭灰 $\mathrm{C}$ & 46.49 & 29.19 & 6.37 & 1.31 & 5.92 & 0.80 & 1.27 & 4.93 & 0.36 & 96.64 \\
\hline 石炭灰 $\mathrm{D}$ & 43.54 & 23.88 & 5.36 & 1.56 & 6.79 & 0.94 & 1.13 & 13.90 & 0.08 & 97.18 \\
\hline
\end{tabular}

$1000 \mathrm{~N}$ 以上）でかつ $15 \pm 5 \%$ 程度の含水率を有する人工骨材（以下 J 骨 材と呼ぶ）を開発することを目的に実験研究を行った。

石炭灰は常磐共同火力 (株) 勿来発電所の粗粉タンクから排出された ものを使用した。当発電所においては, 細粉タンクからは混和材など商 品用となるJIS II 種フライアッシュが排出されている。しかし，粗粉夕 ンクから排出される石炭灰は, これまでの多くの分析結果による実績よ り，JIS規格外の灰あるいはJISIII種のフライアッシュとなる確率が高い ため, 埋立て処分されている。なお，良質な海外炭の燃焼や燃焼効率な どの条件が合致した場合には, 粗粉タンクから少量のフライアッシュ II 種が排出されることもある。したがって, 本論文では, 「未利用のまま 埋立て処分される粗粉タンクから排出される石炭灰」の再利用を目的に 研究対象としているため, 便宜上, 前述した灰を「石炭灰」と称してい る。

本論文は以下の 3項目をまとめたものである。

実験シリーズ 1 : 石炭灰の種類及び混合比率が J 骨材の物性に及ぼす 影響実験

実験シリーズ $2:$ 実機による製造実験

実験シリーズ 3 : 既存軽量骨材との性能比較実験

\section{2. 実験シリーズ 1 : 石炭灰の種類及び混合比率が 」骨材の物性に及ぼ す影響実験}

\section{1 目的}

4種類の石炭灰を用い，これらと頁岩微粉末との混合比率を変えて, 電気炉を用い焼成した $\mathrm{J}$ 骨材の絶乾密度, 吸水率, 圧壊荷重など物性に ついて実験を行った。

\section{2 使用材料}

使用材料は頁岩微粉末と石炭灰を用いた。頁岩は千葉県安房郡鋸南町 産であり, 人工軽量骨材の原料用に破砕されたものをさらに $75 \mu \mathrm{m}$ 以下 に微粉砕したものを用いた。石炭灰は原産地が異なる輸入炭の灰 4 種類 とした。頁岩微粉末および石炭灰の組成分析結果を表1に，石炭灰の密 度および比表面積を表2に示す。組成分析の合計が $100 \%$ にならなの は, 分析対象外の物質が存在するためである。頁岩微粉末の主成分 は, $\mathrm{SiO}_{2}$ 約 $70 \%, \mathrm{Al}_{2} \mathrm{O}_{3}$ 約 $13 \%$ であ。石炭灰は炭種によって異なり, $\mathrm{SiO}_{2}$ 約 $42 \sim 46 \%, \mathrm{Al}_{2} \mathrm{O}_{3}$ 約20〜30\%であリ, $\mathrm{CaO}$ が6〜18\% とやや広い範囲を とっている。なお，これらの石炭灰はフロ一值比や活性度指数を測定し ていないが，JIS A 6201 「コンクリート用フライアッシュ」の品質をみ ると，石炭灰 $\mathrm{C}$ を除き, $\mathrm{SiO}_{2}$ や強熱減量の規定值を超えた JIS規格外の灰 とみなすことができる。

\section{3 実験項目および方法}

(1) 実験の組合せ 石炭灰Aについては石炭灰：頁岩微粉末を $0 ： 100 〜 100 ： 0$ （質量比）
表 2 石炭灰の密度および比表面積

\begin{tabular}{c|c|c}
\hline 種類 & $\begin{array}{c}\text { 密度 } \\
\left(\mathrm{g} / \mathrm{cm}^{3}\right)\end{array}$ & $\begin{array}{c}\text { 比表面樍 } \\
\left(\mathrm{cm}^{2} / \mathrm{g}\right)\end{array}$ \\
\hline 石炭灰 $\mathrm{A}$ & 2.30 & 4560 \\
\hline 石炭灰 $\mathrm{B}$ & 2.38 & 4800 \\
\hline 石炭灰 $\mathrm{C}$ & 2.26 & 4070 \\
\hline 石炭灰 $\mathrm{D}$ & 2.22 & 4570 \\
\hline
\end{tabular}

まで 混合比率を $10 \%$ 刻みで変化させた。その他の死は，両者の混合比 率を30〜 70\%まで変化させた。石炭灰と頁岩微粉末を混合した後, 直径 $10 \mathrm{~mm}$, 長さ $15 \mathrm{~mm}$ の柱状に成形した。その後, 造粒物は電気炉にて焼 成した。電気炉による焼成温度履歴は, 温度 $300{ }^{\circ} \mathrm{C} て ゙ 10$ 分間予熱後, 10 分間で $1130{ }^{\circ} \mathrm{C}$ まで昇温させた。さらに $1130{ }^{\circ} \mathrm{C} て ゙ 10$ 分間保持・焼成し, そ れ以後は自然放冷した。この温度条件は市販人工軽量骨材をロータリー キルン実機で焼成したものと骨材密度が同等となるように設定したも のである。

\section{(2) 実験項目}

1）絶乾密度および 吸水率

J 骨材の絶乾密度および吸水率は, JIS A 1135 「構造用軽量粗骨材の密 度及び吸水率測定方法」に準じた。ここで，吸水率は，絶乾状態の骨材 を24時間吸水させ表乾状態として求めたので，以後24時間吸水率と呼 ぶ。

2) 圧壊荷重

$\mathrm{J}$ 骨材の圧壊荷重は, 先に成形・焼成した円柱造粒物をJIS Z 8841 「造 粒物一強度試験方法」に準じて行った。

3）原料の熱分析

主原料である(1)石炭灰（石炭灰C）と(2)頁岩微粉末及び(3)両者の混合 比率を $60 ： 40$ とした焼成前の造粒物を粉末化したもの, 3試料について 熱分析試験も併せて行った。

\section{4 実験結果および考察}

\section{4.1 石炭灰の種類および混合比率と骨材の諸性質}

（1）絶乾密度および24時間吸水率

石炭灰の種類・混合比率と絶乾密度の関係を図1に示す。

石炭灰の混合比率が 0 ～ $50 \%$ までの範囲では混合比率が増加すると共 に絶乾密度は徐々に大きくなる傾向を示し, 石炭灰の種類によって異な るが,石炭灰混合比率が約50〜 70\%で最大值を示し,70\%を超えると絶乾 密度は小さくなる傾向を示している。

石炭灰の種類・混合比率と24時間吸水率の関係を図2に示す。

$\mathrm{J}$ 骨材の 24 時間吸水率は, 石炭灰混合比率が増加すると共に増大寸る 傾向を示している。特に, 石炭灰混合比率が 0 50\%程度までは, 混合比 率の増加による24時間吸水率の増加の度合いは比較的小さいが, 石炭灰 
混合比率が $70 \%$ を超えると急激に24時間吸水率は増加する傾向にあり， この值は $20 \%$ 以上を示している。このことは石炭灰混合比率が70\%を超 えると骨材の絶乾密度は小さくなり疎な空隙状態になるため, 骨材の吸 水率も大きくなったと考えられる。

\section{（2）圧壊荷重}

石炭灰の種類・混合比率と $\mathrm{J}$ 骨材の圧壊荷重の関係を図3に示寸。

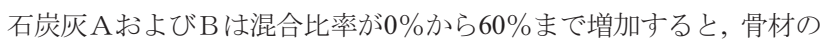
圧壊荷重は徐々に増大し $60 \%$ において最大值を示し, その後混合比率が 増えると減少する傾向にある。石炭灰 $\mathrm{D}$ を用いた J 骨材の圧壊荷重は混 合比率が $50 \%$ において最大值を示し,その後減少する傾向にある。石炭灰 Cの場合は混合比率が $70 \%$ で最大值を示している。なお，混合比率 $80 \%$ のデータを取得していないため，推定となるが，石炭灰Aの圧壊荷重の 結果より混合比率が70\%を超えると圧壊荷重が急激に低下寸る傾向に あることから，石炭灰Cを用いた場合，圧壊荷重が最大值を示すのは石 炭灰混合比率が70\%程度の時と思われる。

これらの結果から, 最大圧壊荷重を示寸石炭灰混合比率の值は石炭灰 の種類によって異なるが, 混合比率が概ね 250 70\%の範囲において最大 圧壊荷重を示寸傾向にあることが明らかになった。

石炭灰の混合比率が70\%を超えるような場合においては，今回の焼成 温度条件下では,頁岩微粉末の含有量が極めて少ないため石炭灰を十分 に結合することができず，骨材中に疎な空隙が増えることによって圧壊 荷重が低下したものと考えられる。しかし，石炭灰の混合比率が $80 \%$ に おける圧壊荷重は, 市販の頁岩微粉末単味焼成骨材（石炭灰混合比率が $0 \%$ ）圧壊荷重よりも大きい值を示しており, 強度が劣っているわけで はない。

以上のことより,石炭灰と頁岩微粉末の 2 成分系を主原料とした $\mathrm{J}$ 骨材 は, 両者の混合比率を変化させることによって,骨材の物性が変化し, 石 炭灰の混合比率を50～70\%程度の範囲にすると,骨材の圧壊荷重は 1000N以上を確保できることがわかった。

海外炭の燃焼によって副産される多種多様な石炭灰の品質変動に対 しても，予石炭灰の受け入れ時に，石炭灰の混合比率を 50 ～70\%の範 囲で変えて, 電気炉で焼成し, 骨材の圧壊荷重の確認試験を行い,最適な 混合比率を定めることにより,品質が安定した骨材が製造できることを 示唆している。

\subsection{2 主原料および混合品の熱分析試験結果}

熱分析装置を用い主原料および混合品のTG一DTA曲線を測定した。 測定温度の範囲は20 $1300{ }^{\circ} \mathrm{C}$, 昇温速度は $10{ }^{\circ} \mathrm{C} /$ 分とした。石炭灰の熱 分析試験結果の例（石炭灰 $\mathrm{C}$ ）を図4に，頁岩微粉末の結果を図5に，両 者の混合粉末（石炭灰C : 頁岩微粉 $=60 ： 40 ）$ の結果を図6に示す。

石炭灰 CのTG-DTA曲線は, $120^{\circ} \mathrm{C}$ 位まで水分の放出により僅かに質 量が減少し吸熱反応を示している。その後元に戻り $450^{\circ} \mathrm{C}$ 付近から, 未然 カーボンの燃焼と考えられる微小の発熱がある。以後吸熱反応が続くが これは主として結合水の放出によるものであり，その後は $1300^{\circ} \mathrm{C}$ ま大 きな変化はみられない。

頁岩微粉末のTG-DTA曲線は, 初め水分の放出により急激な質量減 があり, 吸熱反応を示している。その後, 元に戻り 400 450 $\mathrm{C}$ から未然 カーボンの燃焼と考えられる微小の発熱がある。その後は吸熱を続け, $1200^{\circ} \mathrm{C}$ から急激な吸熱をするのは融解によるものである。

石炭灰C と頁岩微粉末を60：40で混合したものは，ほぼ両者のTGDTA曲線を単純合算したものに近いので, $1200^{\circ} \mathrm{C}$ 付近まで加熱中の化学

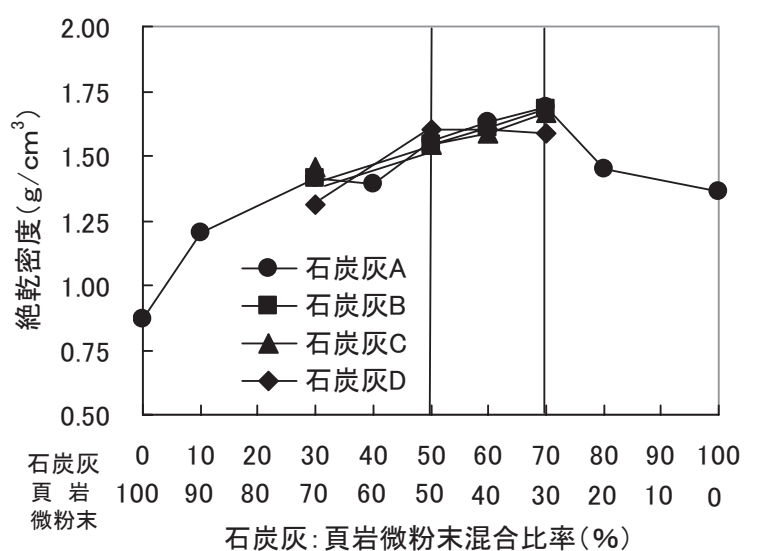

図 1 石炭灰の種類・混合比率と絶乾密度の関係

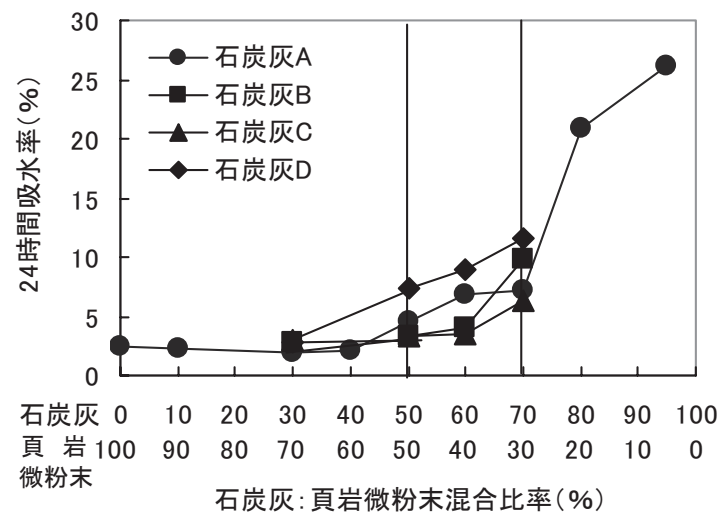

図 2 石炭灰の種類 - 混合比率と 24 時間吸水率の関係

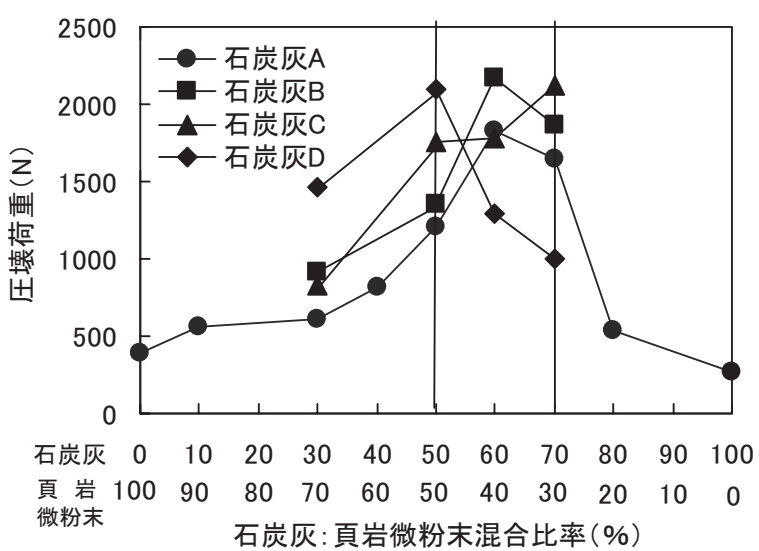

図 3 石炭灰の種類・混合比率と圧壊荷重の関係 ${ }^{4)}$

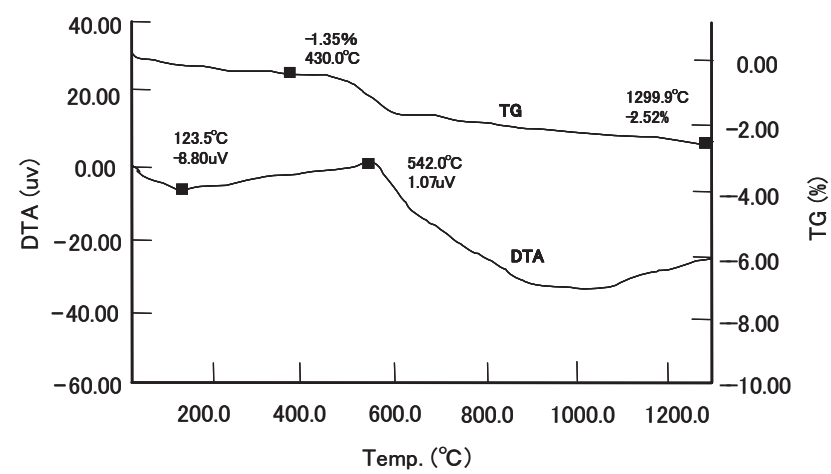

図 4 熱分析試験結果（石炭灰 $\mathrm{C}$ 単味） 


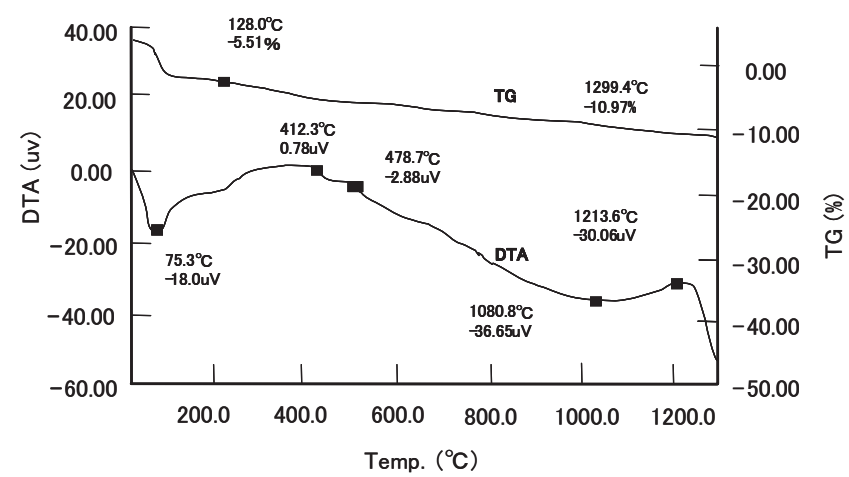

図 5 熱分析試験結果（頁岩微粉末単味）

反応は殆ど同様と思われる。なお，一般に石炭灰の融点は $1300^{\circ} \mathrm{C}$ 付近と 言われている。これらの結果から, 本骨材は頁岩微粉末が石炭灰よりも 先に溶融し，石炭灰を包み込んだ状態で焼結しているものと考えられ る。

\section{3. 実験シリーズ 2：実機による製造実験}

3.1 実験目的

既存の人工軽量骨材実機プラントにおいて目標圧壊荷重 $1000 \mathrm{~N}$ 超 える J 骨材が製造可能であるかを把握するため製造実験を行った。なお， 実験は石炭灰の種類と両者の混合割合を変えて5水準実施した。

なお,製造実験No.1〜2は既往の結果 ${ }^{1)}{ }^{2)}$ であり, No.3〜 5が今回新たに 加えたものである。

\section{2 原料および骨材の調合}

主原料は石炭灰と頁岩微粉末を用いた。

実機による製造で用いた石炭灰の品質試験結果を表3に示す。なお,こ れらの石炭灰は，実験シリーズ1で用いたものとは異なるものである。 化学分析の結果, 製造実験No.4の石炭灰はJIS A 6201 「コンクリート用フ ライアッシュ」の品質規格によると【I種に相当するフライアッシュであ ったが, その他の灰は而種に相当するものであった。頁岩は千葉県安房 郡鋸南町産であり, 一般の人工軽量骨材の原料である膨張性頁岩を微粉 砕したものを用いた。その他，造粒性を高めるために粘結材として，心゙ ントナイトおよび特殊有機系粘結材（外割 $0.4 \%$ ）を用いた。

骨材の調合は，表4に示すとおり製造実験No.1では石炭灰 : 頁岩微粉 末はベントナイトを外割とした場合70 : 30 (ベントナイトを内割りとし た場合, 石炭灰 : 頁岩微粉末 : ベントナイト $=67: 28: 5)$ とし, 製造実 験No.2では60：40（石炭灰 : 頁岩微粉末：ベントナイト $=57: 38: 5$ ) とした。製造実験No.3〜 5は圧壊荷重1000Nを目標とした調合である。 混練水は製造実験No.1〜 5ともに全原料の外割で約 $20 \%$ とした。

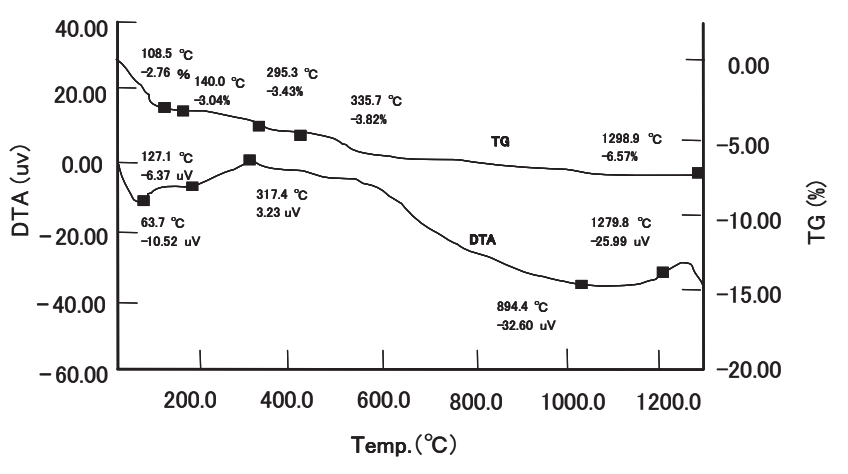

図 6 熱分析試験結果（石炭灰 C : 頁岩微粉末 $=60 ： 40$ )

\section{3 J骨材の製造方法}

$\mathrm{J}$ 骨材の製造工程を図7に示す。製造方法の概要を次に示す。

(1) タンクから排出された各原料は, 計量器で所定量を計量し, 粉体攪 拌混合機で攪拌した後, スクリュー型の混合機内で加水・混練した。

（2）混練した材料は，ロール型押し出し造粒機で造粒し，生ペレットを 得た。生ペレットの形状は直径 $5 \sim 13 \mathrm{~mm}$, 長さ10〜15mmの円柱体であ る。

（3）生ペレットは振動ふるいでふるった後, 直径 $3 \mathrm{~m}$, 長さ $60 \mathrm{~m}$ のロー タリーキルンで焼成し J 骨材を製造した。骨材の焼成温度はキルン挿 入口で約 $200 \sim 300{ }^{\circ} \mathrm{C}$, キルン内で約 $1100 \sim 1200{ }^{\circ} \mathrm{C}$ とた。

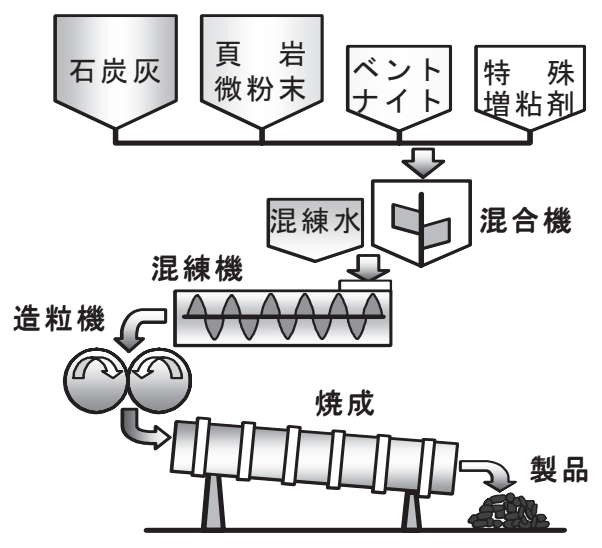

図 7 J 骨材の製造工程

\section{4 実験項目および方法}

J 骨材の絶乾密度および24時間吸水率は, JIS A 1135 「構造用軽量粗骨 材の密度及び吸水率測定方法」に準じた。

J 骨材の圧壊荷重は,JIS Z 8841 「造粒物一強度試験方法」に準じた。

表 3 実機製造に用いた石炭灰の品質

\begin{tabular}{|c|c|c|c|c|c|c|c|c|c|}
\hline \multirow{2}{*}{$\begin{array}{c}\text { 製造実験 } \\
\text { No. }\end{array}$} & \multirow{2}{*}{$\begin{array}{l}\mathrm{SiO}_{2} \\
(\%)\end{array}$} & \multirow{2}{*}{$\begin{array}{l}\text { 湿分 } \\
(\%)\end{array}$} & \multirow{2}{*}{$\begin{array}{c}\text { 強熱減量 } \\
(\%)\end{array}$} & \multirow{2}{*}{$\begin{array}{c}\begin{array}{c}\text { 密度 } \\
\left(\mathrm{g} / \mathrm{cm}^{3}\right)\end{array} \\
\end{array}$} & \multirow{2}{*}{$\begin{array}{l}\text { 比表面積 } \\
\left(\mathrm{cm}^{2} / \mathrm{g}\right)\end{array}$} & \multirow{2}{*}{$\begin{array}{c}\text { フロ一值比 } \\
(\%)\end{array}$} & \multicolumn{2}{|c|}{ 活性度指数(\%) } & \multirow{2}{*}{$\begin{array}{l}\text { フライアッシュ } \\
\text { JIS品質分類 }\end{array}$} \\
\hline & & & & & & & 28日 & 91日 & \\
\hline 1 & 59.2 & 0.4 & 5.5 & 2.16 & 4970 & 70 & 84 & 96 & 正種 \\
\hline 2 & 49.0 & 0.5 & 5.8 & 2.35 & 4580 & 99 & 89 & 96 & 亚種 \\
\hline 3 & 57.4 & 0.2 & 7.9 & 2.29 & 5280 & 95 & 85 & 96 & III種 \\
\hline 4 & 56.4 & 0.2 & 2.2 & 2.15 & 3860 & 102 & 82 & 94 & I 種 \\
\hline 5 & 54.0 & 0.4 & 6.5 & 2.26 & 5210 & 99 & 80 & 92 & III種 \\
\hline
\end{tabular}


表 4 実機製造実験結果

\begin{tabular}{|c|c|c|c|c|c|c|c|c|c|c|c|c|c|}
\hline \multirow{2}{*}{$\begin{array}{l}\text { 製造 } \\
\text { 実験 } \\
\text { No. }\end{array}$} & \multirow{2}{*}{$\begin{array}{c}\text { 石炭灰 } \\
\text { 混入率 } \\
(\%)\end{array}$} & \multirow{2}{*}{$\begin{array}{c}\text { 頁岩微粉 } \\
\text { 末混入率 } \\
(\%)\end{array}$} & \multirow{2}{*}{$\begin{array}{c}\text { ベントナイト } \\
\text { 混入率 } \\
(\%)\end{array}$} & \multirow{2}{*}{ 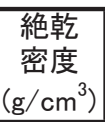 } & \multirow{2}{*}{$\begin{array}{c}\text { 24時間 } \\
\text { 吸水率 } \\
(\%)\end{array}$} & \multirow{2}{*}{$\begin{array}{l}\text { 压壊 } \\
\text { 荷重 } \\
(\mathrm{N})\end{array}$} & \multirow{2}{*}{$\begin{array}{c}\text { 単位容 } \\
\text { 積質量 } \\
(\mathrm{kg} / \mathrm{I})\end{array}$} & \multirow{2}{*}{$\begin{array}{c}\text { 実積率 } \\
(\%)\end{array}$} & \multicolumn{4}{|c|}{ ふるい分け試験（通過率\%） } & \multirow[t]{2}{*}{ 粗粒率 } \\
\hline & & & & & & & & & 20 & 15 & 10 & 5 & \\
\hline 1 & 67 & 28 & 5 & 1.52 & 17.2 & 327 & 1.073 & 69.5 & 100 & 100 & 86 & 37 & 5.62 \\
\hline 2 & 57 & 38 & 5 & 1.51 & 8.2 & 1136 & 1.016 & 67.4 & 100 & 100 & 84 & 44 & 5.57 \\
\hline 3 & 60 & 35 & 5 & 1.57 & 10.5 & 1036 & 1.046 & 66.6 & 100 & 100 & 75 & 22 & 6.04 \\
\hline 4 & 55 & 40 & 5 & 1.42 & 7.1 & 1337 & 0.970 & 67.2 & 100 & 100 & 79 & 31 & 5.84 \\
\hline 5 & 55 & 40 & 5 & 1.62 & 10.9 & 1160 & 1.050 & 64.0 & 100 & 100 & 87 & 52 & 5.17 \\
\hline
\end{tabular}

表 5 JIS A 5002 試験結果

\begin{tabular}{|c|c|c|c|c|c|c|c|c|c|c|}
\hline \multirow{2}{*}{$\begin{array}{c}\text { 製造 } \\
\text { 実験 } \\
\text { No }\end{array}$} & \multicolumn{3}{|c|}{ 化学試験 } & \multicolumn{4}{|c|}{ 物理試験 } & \multicolumn{2}{|c|}{ コンクリート試験 } & \multirow{2}{*}{$\begin{array}{l}\text { 人工軽量骨 } \\
\text { 材の呼び名 }\end{array}$} \\
\hline & $\begin{array}{l}\text { 強熱 } \\
\text { 減量 } \\
(\%) \\
\end{array}$ & $\begin{array}{l}\mathrm{SO}_{3} \\
(\%)\end{array}$ & $\begin{array}{l}\mathrm{NaCl} \\
(\%)\end{array}$ & $\begin{array}{c}\text { 絶乾 } \\
\text { 密度 } \\
\left(\mathrm{g} / \mathrm{cm}^{3}\right)\end{array}$ & $\begin{array}{c}\text { 有機 } \\
\text { 不純物 }\end{array}$ & $\begin{array}{l}\text { 粘土 } \\
\text { 塊量 } \\
(\%)\end{array}$ & $\begin{array}{c}\text { 実積率 } \\
(\%)\end{array}$ & $\begin{array}{c}\text { 単位容 } \\
\text { 積質量 } \\
(\mathrm{kg} / \mathrm{I})\end{array}$ & $\begin{array}{c}\text { 圧縮 } \\
\text { 強度 } \\
\left(\mathrm{N} / \mathrm{mm}^{2}\right)\end{array}$ & \\
\hline 2 & 0.09 & 0.17 & 0.001 & 1.50 & $\begin{array}{l}\text { 標準色 } \\
\text { より淡い }\end{array}$ & 0.03 & 65.3 & 1.943 & 48.2 & $\mathrm{HA}-419$ \\
\hline 3 & 0.75 & 0.16 & 0.001未満 & 1.57 & $\begin{array}{l}\text { 標準色 } \\
\text { より淡い } \\
\end{array}$ & 0.00 & 63.6 & 2.031 & 62.8 & $\mathrm{HA}-421$ \\
\hline 4 & 0.00 & 0.21 & 0.001未満 & 1.40 & $\begin{array}{l}\text { 標準色 } \\
\text { より淡い }\end{array}$ & 0.10 & 64.3 & 1.913 & 66.1 & $M A-419$ \\
\hline 5 & 0.25 & 0.16 & 0.001 & 1.64 & $\begin{array}{l}\text { 標準色 } \\
\text { より淡い } \\
\end{array}$ & 0.20 & 64.0 & 2.064 & 61.0 & $\mathrm{HA}-421$ \\
\hline $\begin{array}{l}\text { 規格值 } \\
\text { 区 分 }\end{array}$ & $\begin{array}{c}1 \\
\text { 以下 }\end{array}$ & $\begin{array}{c}0.5 \\
\text { 以下 }\end{array}$ & $\begin{array}{l}0.01 \\
\text { 以下 }\end{array}$ & $\begin{array}{l}\text { 区分M } \\
\text { 区分H }\end{array}$ & $\begin{array}{l}\text { 標準色 } \\
\text { より淡い }\end{array}$ & 1以下 & 区分A & $\begin{array}{l}\text { 区分19 } \\
\text { 区分21 }\end{array}$ & 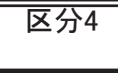 & \\
\hline
\end{tabular}

単位容積質量および実積率は, JIS A 1104 「骨材の単位容積質量及び実 積率試験方法」によった。

ふるい分け試験は, JIS A 1102 「骨材のふるい分け試験方法」によった。

また，製造実験No2〜 5の J 骨材については, 公的機関に於いて, JIS A 5002 「構造用軽量コンクリート骨材」試験を行った。なお, 製造実験No.1 の J 骨材の圧壊荷重は1000Nに達しなかったため公的試験を行わなかっ た。

(1) 実機による製造実験結果

実機による製造実験結果を表4に示す。

製造実験No.1における骨材の絶乾密度は $1.52 \mathrm{~g} / \mathrm{cm}^{3}, 24$ 時間吸水率は 17.2\%を得た。圧壊荷重は，327Nであり,1000Nに達しなかった。

製造実験No.2の場合，骨材の絶乾密度はNo.1の場合と同等であった が，圧壊荷重は大幅に増加し1000Nを超えるものであった。24時間吸水 率は8.2\%であった。ここで, 製造実験No.1とNo.2の比較において, 石炭 灰の種類が異なるため一概には言えないが, 焼成時の結合バインダーと なる頁岩微粉末の混入率の違いが圧壊荷重や24時間吸水率の差異に影 響を及ぼしているものと思われる。

製造実験No.3の場合，骨材の絶乾密度はやや大きい值を示したが，圧 壊荷重は1000Nを超え,24時間吸水率は10.5\%であった。

製造実験No.4の場合，骨材の絶乾密度は，その他の場合に比べてやや 小さい值を示したが，圧壞荷重はその他の場合に比べて最も大きい $1337 \mathrm{~N}$ 示した。24時間吸水率は7.1\%で, No.2の場合とほぼ同程度であ った。

製造実験No.5の場合，骨材の絶乾密度は最も大きい值を示した。圧壊 荷重は1160Nであり，No.4の次に大きかった。

なお，製造実験No.2 5の骨材含水率は，焼成工程後に骨材温度が約 $200 \sim 300^{\circ} \mathrm{C}$ になった時点で水に浸漬させる, 熱間吸水を行い $12 \sim 15 \%$ を 確保した。

（2）JIS A 5002「構造用軽量コンクリート骨材」試験の結果
製造実験No.2～5の骨材の JIS A 5002による試験結果を表5に示す。 なお，表4で得られたふるい分け試験結果を基に，適切な粒度となる ようにJ 骨材は粒度調整した。表5より，製造実験No.2〜 5の骨材はいら れも JIS A 5002 試験の規格值に適合していた。なお, No.2の焼成骨材は JIS による呼び名はHA－419品であったが，No.3とNo.5の骨材はHA421品であった。No.4の骨材は絶乾密度がその他の骨材よりも約7 11\% 小さく, その呼び名はMA-419品であった。しかし, No.4の骨材を用いた コンクリート圧縮強度はその他の骨材を用いた場合よりも最も大きく, 最も軽量で高強度の性能を保持した骨材が得られた。以上のように, 石

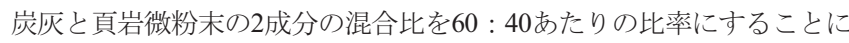
よって, 既存の人工軽量骨材の製造設備を用いても目標とする高強度軽 量骨材を製造できることを検証できた。

\section{4. 実験シリーズ 3 : 既存軽量骨材との性能比較実験}

4. 1 目的

実機により製造した骨材は，既存の軽量骨材と比較した場合に，同一 試験条件下においてどのような性質を有しているかを把握することを 目的に各種の実験を行った。

\section{2 使用材料}

使用した骨材は10〜15mmのものとし，以下の5種類とした。

実験シリーズ2における製造実験No.3により製造した骨材（J 3 と呼 ぶ），同様に製造実験No.4により製造した骨材（ J 4 と呼ぶ）および比較 用に既存の人工軽量骨材 3 種類（既存骨材 $\mathrm{A}$ はフライアッシュ系, Bは膨 張頁岩系, Cは下水污泥焼却灰系）とした。

\section{3 実験項目及び方法}

(1) 絶乾密度

骨材の絶乾密度 : JIS A 1135 「構造用軽量粗骨材の密度及び吸水率試 験方法」に準じた。

（2）骨材の圧壊荷重 
骨材の圧壊荷重：JIS Z 8841 「造粒物一強度試験方法」に準じた。 試験に供した骨材は絶乾状態とし, 各々 $\mathrm{n}=30$ 試料数とした。

（3）煮沸による骨材の吸水率

試験に供した骨材試料は絶乾状態とし, 試料を煮沸容器内の水中に沈 め, 徐々に加熱して90分間煮沸した。その後, 試料は自然冷却し, 表面水 を拭き取り表乾状態で表乾質量 $\left(\mathrm{A}_{\mathrm{w}}\right)$ を測定した。さらに, 表乾試料は $105{ }^{\circ} \mathrm{C}$ 乾燥炉内で絶乾状態まで乾燥し絶乾質量 $\left(\mathrm{A}_{\mathrm{D}}\right)$ を測定した。煮 沸後の吸水率 $\left(\mathrm{F}_{\mathrm{Q}}\right)$ は次式によって算出した。

$$
\mathrm{F}_{\mathrm{Q}}=\left[\left(\mathrm{A}_{\mathrm{w}}-\mathrm{A}_{\mathrm{D}}\right) / \mathrm{A}_{\mathrm{D}}\right] \times 100(\%)
$$

\section{（4）加圧吸水試験装置による骨材の圧力吸水性状}

$\mathrm{J}$ 骨材の圧力吸水性状を把握するため, 既往の文献 ${ }^{8)}$ を参考に, 加圧 吸水試験を行った。加圧吸水試験装置は, 日本メサライト工業社製のもの を用いた。その装置は, 圧力容器, 手動ポンプ及び給水タンクから構成 されている。試験に供した骨材は十分に含水させ，表乾状態とした。こ の試料 (約 $1 \mathrm{~kg}$ ) を計量後, 所定の網状容器に詰め, 円筒型の圧力容器 (内 法寸法 $\Phi 150 \times \mathrm{H} 278 \mathrm{~mm})$ にセットし満水した。その後, 圧力容器のふた をボルト締めした。さらに, 圧力容器に手動ポンプと給水タンクを連結 した。手動ポンプを用いて圧力容器内に水を供給し, 容器中の空気を追 い出し, 圧力容器を試料と水で満たした。手動ポンプと給水タンクを取 り外した後, 試料を含む満水状態の圧力容器の全質量を測定した。さら に, 圧力容器に手動ポンプと給水タンクをセットし, 手動ポンプで水を 供給し, 容器内の圧力を上昇させ， $1 \mathrm{~N} / \mathrm{mm}^{2}$ の圧力に達した後，3分間圧 力を保った後, 手動ポンプと給水タンクを取り外し, 同容器の全質量を 測定した。以後 $1 \mathrm{~N} / \mathrm{mm}^{2}$ ごとに $5 \mathrm{~N} / \mathrm{mm}^{2}$ までポンプで加圧し, 各圧力状態 下における容器質量を測定した。加圧前と加圧後の全質量差を加圧吸水 量とした。 $5 \mathrm{~N} / \mathrm{mm}^{2}$ まで加圧した後, 圧力弁を解放し, 圧力容器内の圧力 を0に戻し除圧した。以後除圧時の圧力容器の全質量を60分まで経時測
定した。なお，除圧によって排出される水は圧力容器の圧力弁から取り 除いた。

測定終了後, 容器から試料を取り出し表面水を拭き取り, 表乾質量を 測定した。さらに, 表乾試料は $105{ }^{\circ} \mathrm{C}$ 乾燥炉内で絶乾状態まで乾燥し絶 乾質量を測定した。なお，既存骨材Cについては加圧吸水試験を行って いない。

\section{（5）骨材の細孔径分布}

骨材の微細構造は，アセトン洗浄後24時間凍結乾燥（F-Dry）を行い， 水銀圧入法により細孔径分布を測定した。

（6）骨材の顕微鏡による断面観察

骨材の断面を研磨し, 観察用試料を作製した後, 光学顕微鏡で断面の 写真撮影を行った。

\section{4 実験結果及び考察}

各種骨材の試験結果を一括して表6に示す。

（1）絶乾密度・圧壞荷重

表6より，J3および J4の絶乾密度は, 既存の軽量骨材よりも若干大 きい值を示したが，J3および J4の圧壊荷重は既存の軽量骨材よりも 約2４倍大きい值を示した。ここで，比圧壊荷重 (圧壊荷重／絶乾密度） を比較すると，J 3, J 4, 既存A，B，Cは，各々 713，1071，427, 515, $456 \mathrm{~N}$. $\mathrm{cm}^{3} / \mathrm{g}$ であり，J3および $\mathrm{J} 4$ 他に比し大きく, 特に J 4が軽量で高強度 な骨材性状を示している。

\section{（2）煮沸吸水率}

各種骨材の煮沸吸水率を比較すると，J 3および J 4の煮沸吸水率 は14〜16\%を示し，その他の骨材よりも小さい值を示した。特に,絶乾密 度 $1.0 \mathrm{~g} / \mathrm{cm}^{3}$ 以下の超軽量骨材である既存骨材 $\mathrm{C}$ の煮沸吸水率の $1 / 4$ 程度

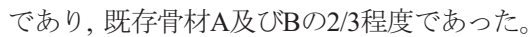

（3）総細孔量と絶乾密度, 圧壊荷重及び煮沸吸水率

各種骨材の総細孔量と絶乾密度, 圧壊荷重及び煮沸吸水率の関係を図 8～10に示す。図8より骨材の総細孔量が大きくなる程骨材の絶乾密度は

表 6 各種骨材の諸性質の試験結果

\begin{tabular}{c|c|c|c|c|c}
\hline \multirow{2}{*}{ 試験項目 } & \multicolumn{5}{|c}{ 骨材の種類 } \\
\cline { 2 - 6 } & $\mathrm{J} \mathrm{3}$ & $\mathrm{J} 4$ & 既存A & 既存B & 既存C \\
\hline 絶乾密度 $\left(\mathrm{g} / \mathrm{cm}^{3}\right)$ & 1.57 & 1.41 & 1.35 & 1.27 & 0.80 \\
\hline 圧壊荷重 $(\mathrm{N})$ & 1120 & 1510 & 576 & 654 & 365 \\
\hline 比圧壊荷重 $\left(\mathrm{N} \cdot \mathrm{cm}^{3} / \mathrm{g}\right)$ & 713 & 1071 & 427 & 515 & 456 \\
\hline 煮沸吸水率 $(\%)$ & 16.0 & 13.7 & 23.1 & 28.3 & 59.9 \\
\hline $5 \mathrm{~N} / \mathrm{mm}^{2}$ 加圧時における含水率 $(\%)$ & 27.2 & 22.9 & 30.8 & 34.3 & - \\
\hline 除圧60分後における含水率 $(\%)$ & 16.5 & 14.2 & 21.7 & 29.2 & - \\
\hline 総細孔量 $(\mathrm{ml} / \mathrm{g})$ & 0.198 & 0.162 & 0.328 & 0.391 & 0.736 \\
\hline
\end{tabular}

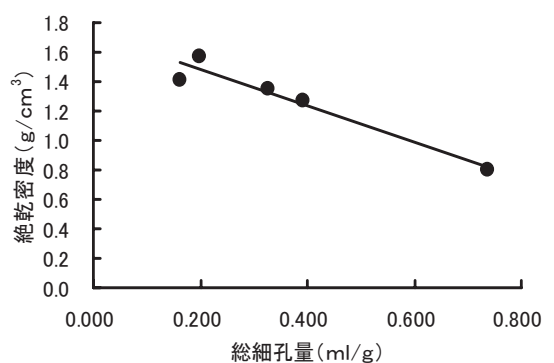

図 8 各種骨材の総細孔量と絶乾密度

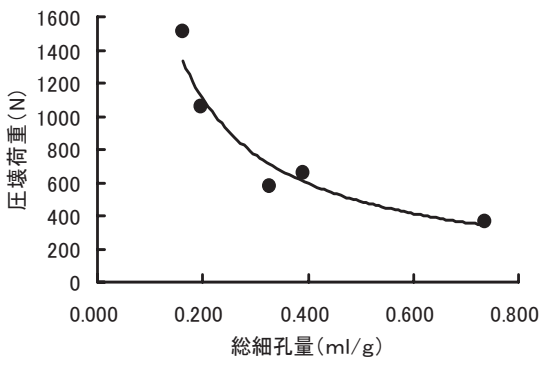

図 9 各種骨材の総細孔量と圧壊荷重

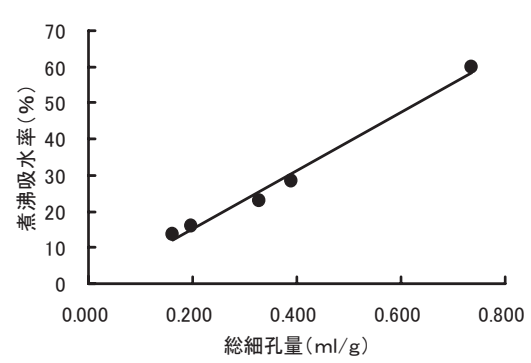

図 10 各種骨材の総細孔量と煮沸吸水率 
表 7 各種骨材の断面観察結果の一例

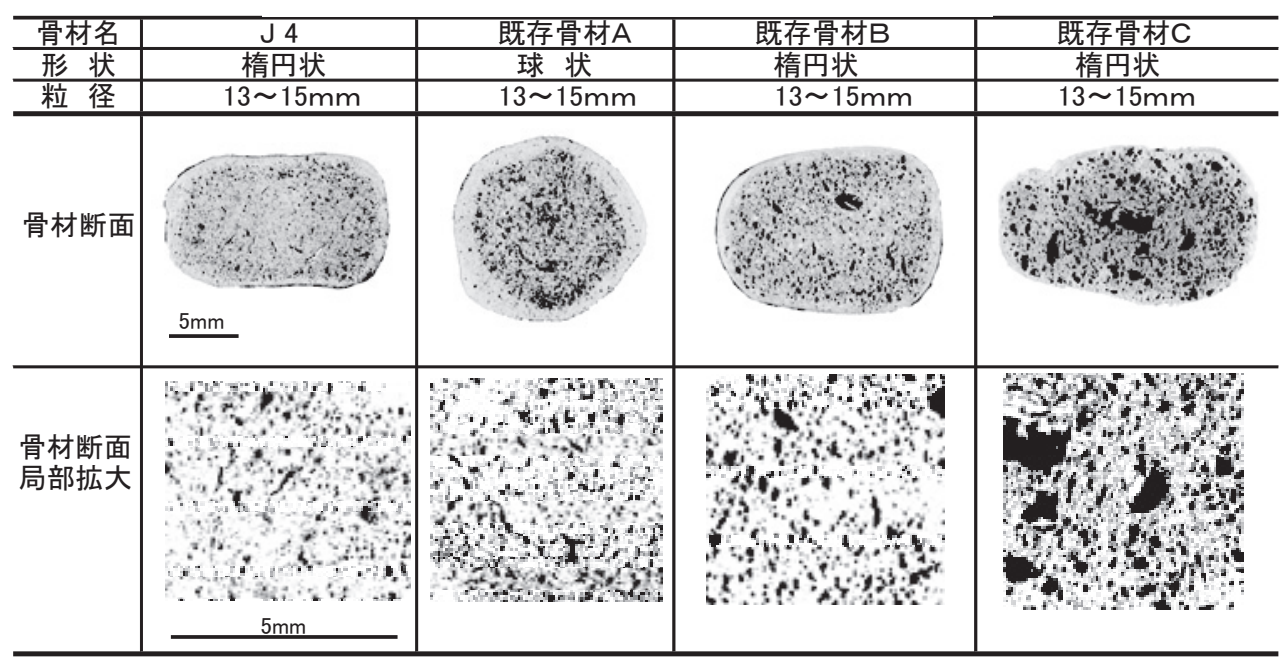
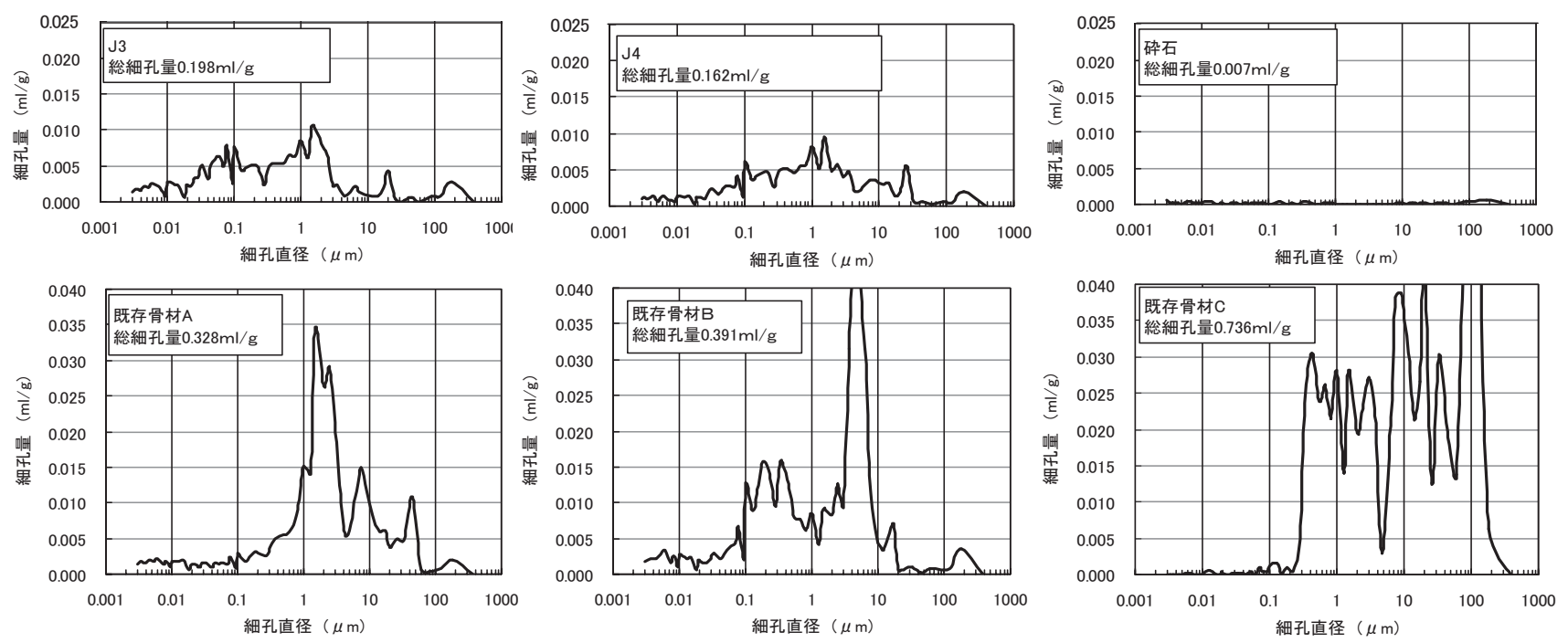

図 11 各種骨材の細孔径分布試験結果

小さくなる傾向を示した。

図9より骨材の総細孔量が大きくなる程骨材の圧壊荷重は指数的に小 さくなる傾向を示した。

図10より，骨材の総細孔量が大きくなる程骨材の煮沸吸水率は直線的 に大きくなる傾向を示した。骨材の総細孔量と諸性質とには相関的な傾 向が認められ，骨材の特性を把握する上で骨材の細孔量を測定すること は, 極めて有用な情報が得られることを示した。

各種骨材の細孔径分布試験の結果を図11に示寸。骨材の総細孔量が最 も小さかったのは砕石であり, ほとんど空隙が認められなかった。J 3 および J 4の総細孔量は, 既存骨材 $\mathrm{A}$ 及びBの場合より, 1/3〜1/4程度少な

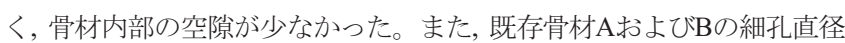
は $1 \sim 10 \mu \mathrm{m}$ の割合が多いのに比し，J 3および J 4は $0.1 〜 1 \mu \mathrm{m}$ の割合 が多く, 既存骨材とは細孔の分布が明らかに異なっていた。従って，J3 および J 4は, 既存骨材よりも総細孔量が少なく, その細孔も小さいこ とから, 緻密な組織を形成していると言える。

\section{（4）骨材断面の観察}

粒径 13〜15mmにおける各種骨材の断面観察結果の一例を表7に示 す。 J 4の骨材形状は既存骨材BおよびCと同様に楕円状であるのに対し，
既存骨材Aは球状であった。これは製造時の造粒方法の違いによるもの である。

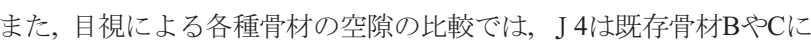
比べて, 骨材断面に対して小さい空隙が観察された。J4は既存骨材 $\mathrm{A} に$ 比べて, 空隙の大きさは同程度であるが, 空隙の量が少ない傾向にあっ た。

（5）加圧吸水試験装置による骨材の圧力吸水性状

加圧吸水試験装置による各種骨材の圧力吸水性状を図12に示す。試験 開始時における J 3及び J 4の含水率は $14.5 \%$ 及び $12.5 \%$ であり, 既存骨

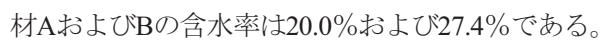

これより, 各種骨材の含水率は加圧力 $1 \mathrm{~N} / \mathrm{mm}^{2}$ 時に急激に増加し, それ 以降は加圧の増加と共に徐々に増加し, $5 \mathrm{~N} / \mathrm{mm}^{2}$ 加圧時においてほぼ平 衡状態となった。これは, 加圧による圧力吸水によって, 骨材の含水率 が増加したためと言える。 $5 \mathrm{~N} / \mathrm{mm}^{2}$ 加圧時における各種骨材の含水率は, 既存骨材B (34.3\%) > 既存骨材A (30.8\%) > J3 (27.2\%) > J4 (22.9\%) の順であった。

これは, 図11や表7に見られるように，J3および J 4の総細孔量が既存 骨材AおよびBよりも少ないためと思われる。 


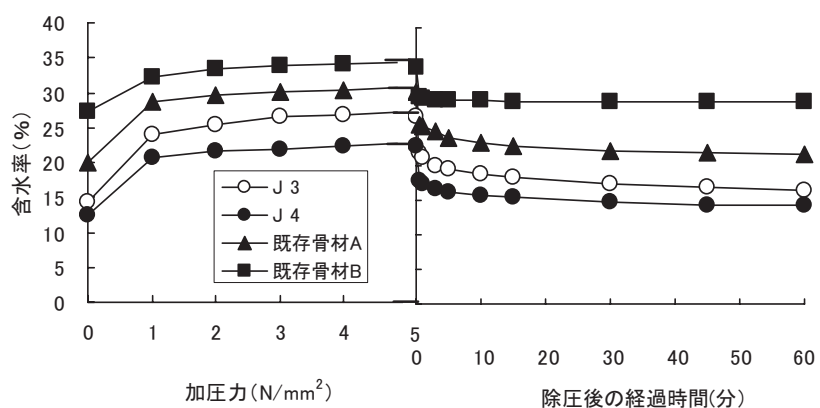

図 12 加圧吸水試験装置による各種骨材の圧力吸水性状

$5 \mathrm{~N} / \mathrm{mm}^{2}$ 除圧後における各種骨材の含水率は，約10分まで急激に減少 し，その後は緩やかであった。既存骨材 $\mathrm{B}$ は殆ど変化しなかった。

$5 \mathrm{~N} / \mathrm{mm}^{2}$ 除圧 60 分後の含水率と試験開始時の含水率の差を図13に示 す。何れの骨材も両者の含水率の差は $2 \%$ 以内となっており，小さい值 を示している。

\section{5. 結論}

石炭灰と頁岩微粉末を原料とした人工軽量骨材の開発に関寸る実験 研究を行ない，以下のことが明らかになった。

（1）開発した骨材は既存の人工軽量骨材製造設備の大型キルンを用い て焼成製造できる。

（2）開発した骨材は平均密度 $1.53 \mathrm{~g} / \mathrm{cm}^{3}$ ，圧壊荷重 $1000 \mathrm{~N}$ 以上の高強度 軽量骨材であり，JIS A 5002「構造用軽量コンクリート骨材」に適合 する。

（3）熱分析試験の結果，開発した骨材は頁岩微粉末が $1100^{\circ} \mathrm{C}$ 程度で先 に溶融し，石炭灰を包み込む状態で焼結していると考えられる。

（4）石炭灰の混合比率が大きくなるに従い，開発した骨材の絶乾密度， 圧壊荷重は大きくなるが，50～70\%を超えると, 頁岩微粉末の焼結量 が少なくなるため, 骨材中に疎な空隙が増え, 絶乾密度が小さく, 圧 壊荷重が低下寸る傾向を示す。

（5）骨材の総細孔量と骨材の諸性質（密度, 圧壊荷重, 煮沸吸水率) の関係は関連が認められ，骨材の総細孔量を測定することにより，極 めて有用な骨材特性に関する情報が得られる。

（6）開発した骨材は総細孔量が少なく,その細孔径も小さいことから, 既存の人工軽量骨材より緻密な組織を形成している。

謝辞 : 本論文をまとめるにあたり, 日本大学生産工学部建築工学科, 松井勇教授に多大なご指導を頂きました。感謝の意を表します。

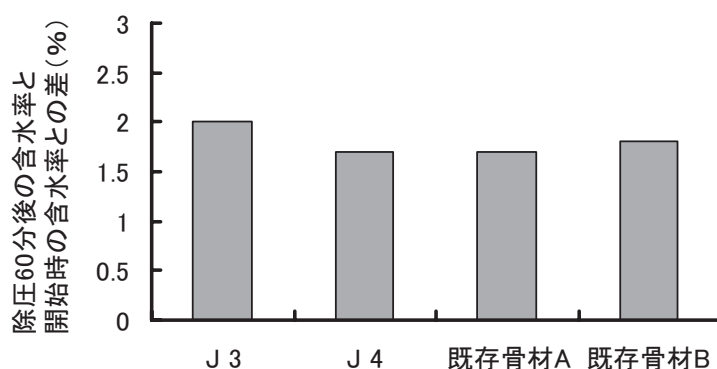

図 13 除圧後 60 分後の含水率と開始時の含水率との差

\section{参考文献}

1) 石川寛範，藤木英一，田中公徳，和美廣喜：石炭灰を用いた人工骨 材の製造方法に関する研究, コンクリート工学年次論文集, Vo1.22, No. 2, pp. 253-258, 2000.6

2）石川寛範，藤木英一，田中公徳，和美廣喜, 笠井浩ほか：石炭灰の 資源化に関する研究（その1石炭灰を用いた人工骨材の開発），日本 建築学会大会学術講演梗概集（東北）, A-1, pp. 603-604,2000.9

3）本庄秀一，林孝幸，和美廣喜，笠井浩ほか：石炭灰の資源化に関 する研究（その 2 人工骨材用バインダーの開発），日本建築学会大 会学術講演梗概集（東北）,A-1，pp605-606，2000.9

4）笠井浩, 全振煥, 鈴木宏一, 渡邊茂雄 : 石炭灰人工骨材（ J ライ 卜）を用いた高性能コンクリートの諸性質，鹿島技術研究所年報， 第53号, pp157-166, 2005.9

5）是石俊文，畠埜晴義，船本憲治：フライアッシュを利用した人工 軽量骨材の開発，セメント・コンクリート，No.478, pp. 18-27. 1986. 12

6）菊地雅史，向井毅：石炭灰軽量骨材の構造用コンクリート骨材と しての適用性（第1報），日本建築学会構造系論文集第402号, pp. 27-36, 1998. 12

7）曾根徳明：石炭灰を主原料とした高強度人工骨材，コンクリート 工学, Vol.36, No. 12, pp. 3-10, 1998. 12

8）日本建築学会：高強度人工骨材（タフライト）を用いたコンクリ 一トに関する委託調査研究報告書, 2001.3

（2008年 2 月 5 日原稿受理，2008年 5 月27日採用決定） 